\title{
Brain and art: illustrations of the cerebral convolutions. A review
}

 \\ M. Grujičić7 , B. Marković ${ }^{8}$
}

${ }^{1}$ Psychiatric Clinic Laza Lazarević, Faculty of Medicine, University of Belgrade, Belgrade, Serbia

${ }^{2}$ Department of Neuroanatomy and Gross Anatomy, Institute of Anatomy, Faculty of Medicine, University of Belgrade, Serbia

${ }^{3}$ Art History, Faculty of Art History, University of Belgrade, Belgrade, Serbia

${ }^{4}$ Department of Pathology, Institute of Pathology, Faculty of Medicine, University of Belgrade, Belgrade, Serbia

${ }^{5}$ Department of Anatomy, Institute of Anatomy, Faculty of Medicine, University of Belgrade, Belgrade, Serbia

${ }^{6}$ Department of Neurosurgery, Clinic of Neurosurgery, Faculty of Medicine, University of Belgrade, Belgrade, Serbia

${ }^{7}$ Head of Emergency Centre, General Hospital, Smederevo, Serbia

${ }^{8}$ Department of Anatomy, Faculty of Sport and Physical Education, University of Belgrade, Belgrade, Serbia

[Received 26 November 2013; Accepted 24 February 2014]

Background: Aesthetics and functional significance of the cerebral cortical relief gave us the idea to find out how often the convolutions are presented in fine art, and in which techniques, conceptual meaning and pathophysiological aspect.

Materials and methods: We examined 27,614 artworks created by 2,856 authors and presented in art literature, and in Google images search.

Results: The cerebral gyri were shown in $0.85 \%$ of the artworks created by $2.35 \%$ of the authors. The concept of the brain was first mentioned in ancient Egypt some 3,700 years ago. The first artistic drawing of the convolutions was made by Leonardo da Vinci, and the first colour picture by an unknown Italian author. Rembrandt van Rijn was the first to paint the gyri. Dozens of modern authors, who are professional artists, medical experts or designers, presented the cerebral convolutions in drawings, paintings, digital works or sculptures, with various aesthetic, symbolic and metaphorical connotation. Some artistic compositions and natural forms show a gyral pattern. The convolutions, whose cortical layers enable the cognitive functions, can be affected by various disorders. Some artists suffered from those disorders, and some others presented them in their artworks. Conclusions: The cerebral convolutions or gyri, thanks to their extensive cortical mantle, are the specific morphological basis for the human mind, but also the structures with their own aesthetics. Contemporary authors relatively often depict or model the cerebral convolutions, either from the aesthetic or conceptual aspect. In this way, they make a connection between the neuroscience and fine art. (Folia Morphol 2014; 73, 3: 247-258)

Key words: brain, cerebral cortex, convolution, fine art, history, psychology

\section{INTRODUCTION}

Homo sapiens sapientis appeared when his cerebral cortex, which covers the surface of the convo- lutions, reached such a structural and organisational complexity to enable him an almost unlimited range of abstract thought, imagery, memory, visual proces-

Address for correspondence: Dr S. Marinković, Institute of Anatomy, Faculty of Medicine, University of Belgrade, Subotić 4/2, 11000 Belgrade, Serbia, tel: +381-11-2645958, fax: +381-11-2686172, e-mail: mocamarinkovic@med.bg.ac.rs 
sing, aesthetic judgments and emotions, that is, all the prerequisites for artistic and scientific creativity $[4,9,10,31,40,45]$. The neural complexity expressed itself in an enormous development of the cerebral convolutions or gyri that became the specific morphological basis for the human mind.

\section{CEREBRAL CONVOLUTIONS}

The term convolution originates from Latin word convolutus referring to the structures rolled together or being infolded upon themselves [17]. This concept was once used for the intestinal loops, while it was employed for the cerebral relief by Erasistratus some 2300 years ago [72]. The term gyrus, that has its origin in Greek gyros meaning the circle or ring, came into use only in the $16^{\text {th }}$ century.

The convolutions or gyri are the most prominent morphological features of the human cerebral hemispheres. The primary and secondary cerebral sulci and gyri were distinguished $[19,39,55,56]$. The former, that begin to appear in the $6^{\text {th }}$ month of fetal life, comprise the central, parieto-occipital, calcarine and Sylvian sulci, which demarcate primordial precentral and postcentral gyri, the parietal and paracentral lobuli, the precuneus and cuneus. The secondary sulci and gyri begin to appear in the $7^{\text {th }}$ month. At the same time, the frontal, temporal, occipital and cingulate gyri develop. Certain of them, especially those on the basal surface of the brain, appear later and may complete their development in the postnatal period.

Many earlier anatomists examined the surface of the cerebral cortex. Some of the convolutions, in addition to their Latin terms, also bear the names of those who first described them, for example, gyrus frontalis, angularis and dentatus (Huxley), gyrus praecentralis and postcentralis, temporalis medius and inferior, cuneatus and fornicatus (Ecker), gyrus temporalis superior (Huschke), gyrus transversus (Heschl), gyrus cinguli and hippocampi (Burdach), and gyrus subcallosus (Zuckerkandl) [19, 72].

The cerebral convolutions and sulci, particularly the secondary ones, are susceptible to great anatomical variations $[19,55]$. In fact, there are no two morphologically identical brains, and even the right and left cerebral hemispheres in the same person differ in their gyral pattern, and they also show the neuronal, biochemical and functional asymmetry, as reported by many authors [1, 2, 6, 10, 20, 53, 63]. Modern neuroscientists, including neurosurgeons, examined the cerebral gyri and sulci in detail for two reasons. Firstly, to make precise morphological, cytoarchitectural, cytochemical and functional maps of the cerebral cortex $[6,19,20,53,55]$ and, secondly, to approach safely the deep pathological processes through the corresponding cerebral gyri by a transcortical incision during neurosurgical operations [61]. Inspired by this scientific brain mapping, contemporary artist Heidi Whitman created the "Brain Terrain" series trying to chart various states of mind.

\section{A HISTORICAL BACKGROUND}

The brain and its convolutions have been attracting some artists, thinkers and scientists since ancient times to the present days $[11,15,27,47,59,71]$.

Our ancestors, who performed a ritual or curative trephination occasionally, made many drawings of the human figures, but they never presented the brain on the cave walls [13]. For the first time in history the word "brain" was mentioned in the Edwin Smith Surgical Papyrus written in the ancient Egypt about 1700 BCE $[40,59]$. The specific heratic signs were designed for the concept of brain, which included a bird drawing and probably instruments for post mortem brain extraction [40]. Yet, the Egyptians, like the Jews later on, regarded the heart, not the brain, as the spiritual centre. Because of that, the heart was left inside the mummies body to help in the afterlife, while the "unimportant" brain was removed through the nasal cavity and nostrils [64].

The Father of Chinese medicine, Huang Ti of 2600 BEC, described many "yang" and "yin" organs, but not the brain $[23,59]$. The famous Indian surgeon Susruta in the $6^{\text {th }}$ century BCE, who performed various operations on his patients, did not pay a special attention to the brain. The Mesopotamian civilisations were more interested in the liver and lungs of animals, for predicting the future, than in the brain [18].

The Greek philosopher in the $5^{\text {th }}$ century BCE Alcmaeon of Croton, who dissected animals and thus was the first scientific anatomist, was also the first to regard the brain as the centre of perception, thought and understanding [14]. Accordingly, he considered the human brain, not the heart, as the seat of the spirit and intelligence. Pythagoras from Samos also adhered to this encephalocentric view.

In the same century, Hippocrates, the Father of Greek medicine [59,69], considered the brain to be a gland secreting mucus, but he still regarded it as the seat of thought and emotions. In addition, he described in the treatise "De capitis vulneribus" 
("On Wounds in the Head"), contrecoup injuries of the brain, skull fractures and trephination or trepannation (from the Greek trypanon for borer) [27, 72]. The philosopher Plato, a student of Socrates, believed that the most important component of the soul, i.e. intellective soul, is located in the head [15]. His student Aristotle regarded the heart as the seat of life and intelligence (cardiocentric view). Yet, according to him, it was the brain that controls the bodily functions [15, 32].

The physician Herophilus (the $3^{\text {rd }}$ century BCE) from the Alexandrian medical school, who dissected more than 600 persons, stated that the cerebral ventricles are the site of the anima spirit (the Latin anima for breath and soul) [59]. His younger contemporary Erasistratus also believed first that the ventricles are the place where the vital spirit is transformed into the anima spirit. However, after having compared the animal and human brain, he inferred that the cerebral convolutions were associated with intelligence.

The famous Roman physician Galen of Pergamum of the $2^{\text {nd }}$ century $C E$, who was court physician to imperator Marcus Aurelius and a surgeon to gladiators, experimented on and dissected animals $[17,70,71]$. According to him, the pneuma (the Greek pneuma for breath and soul), i.e. the life force taken into the body during breathing, reaches the brain by blood to become the anima or psychic spirit in the cerebrum, including the ventricles. Galen regarded the brain as the centre of intelligence, motion and sensation. He examined the cerebral ventricles and some other structures of the brain, and hence the great cerebral vein bears his name (the vein of Galen).

After the fall of the Roman Empire in the $5^{\text {th }}$ century $C E$, the medieval epoch started in Europe with the domination of the pagan magic thought and Christian dogma, so that the dissection and science on the whole virtually ceased to exist the next 1000 years, while art mainly served the Church for the Lord's and Christ's glorification $[12,13]$. As regards the cognitive functions of the brain, only some educated theologians, such as Nemesis and St. Augustine, tried to incorporate Herophilus' and Galen's ventricular doctrine into the religious context $[15,59]$.

Islamic dogma had the same effect on the Arabic culture and science [59]. Later on, however, the rising Islam created the conditions for the appearance of several famous physicians such as Avicenna (the $11^{\text {th }}$ century). Avicenna described in his "Canons of Medicine" several organs and made a crude drawing of the brain stem and spinal cord with the peripheral nerves [27]. The Islamic physicians had also translated the classical Greek philosophic and scientific literature, that was later retranslated into Latin for the Western readers, especially by Constantinus Africanus, Stephen of Antioch, and Gerard of Cremona. Therefore, some Arab terms, or imported Greek words or new Latin terms, are still in use in medical literature, for example, nucha (the Arab nuqrah for spine or spinal cord), iris (rainbow in Greek), epilepsy (the Greek epilepsia for seizure), dura mater ("hard mother" in Latin), pia mater ("soft mother") etc. [72].

The European intellectual awakening began in Salerno (South Italy) and Bologna (North Italy) where the first Universities were founded in the $12^{\text {th }}$ century [71]. A medical text, that originated in Salerno around 1250, was illustrated with a drawing of the human body anatomy [11]. The brain image in that drawing, although made in a very simplistical manner, was the first attempt in history to render the cerebral gyri and sulci, and the brain as a whole.

Before and after that time many medieval scholars, including physicians, created only some conceptual sketches with the main functions of the brain presented on the outer surface of the head [11, 40, 59]. The localisation of the cognitive functions was based on Herophilus' and Galen's doctrine on 3 ventricular, i.e. vesicular or cellular, compartments in the brain. The anterior vesicle or cell was the common sense (sensus communis), that is, the meeting place of the senses, as well as the site of the fantasy and imagination (cellula imaginativa). The middle one was the seat of thinking, reasoning and judgment (cellula cognitativa or estimativa). The posterior vesicle or cell was responsible for memory (cellula memorativa).

Dissections were soon renewed and improved at the University of Bologna, especially by Mondino de Luzzi. At that time and later on, usually were dissected bodies of criminals, who were sometimes executed in a manner chosen by the anatomists [71]. Mondino accepted the mentioned Galen's vesicular (cellular) doctrine and, in addition, believed that mental operations are controlled by a "red worm," that is, the choroid plexus in the ventricles. Mondino wrote in 1316 book "Anathomia", that influenced many anatomists and artists, including Leonardo da Vinci in the $15^{\text {th }}$ century.

The illustrations of the brain itself, usually erroneous ones, were presented rarely between the $14^{\text {th }}$ and the $16^{\text {th }}$ century $[11,32,59]$. Johann Peyligk 
published in 1499 a few very crude drawings of the brain, Magnus Hundt presented in 1501 some inaccurate illustrations of the convolutions, Laurentius Phryesen showed in his 1518 book different stages in brain dissection, and Johann Dryander published in 1536 "Anatomia capitis humani"a few brain images with very simplistical cerebral convolutions. Only a treatise written by Berengario da Carpi contained several neuroanatomical images of certain scientific and aesthetic value.

However, theoretical and practical progress went parallel with each other. Thus, Realdo Colombo regarded the brain as the supreme organ and wrote that it "transmits sense and motion through the nerves..." [32]. Jacobus Sylvius (Jacques Dubois) in the first half of the $16^{\text {th }}$ century examined the ventricular and subarachnoid compartments, some of which bear his name, e.g. the aqueduct, and the lateral hemispheric fissure and cistern. Sylvius and some other physicians improved the anatomical nomenclature by introducing, for instance, the terms corpus callosum (the Latin callosus for hard, like callus), choroid (the Greek chorioid for skin or leather) and carotid (from the Greek karos for deep sleep) [71, 72].

\section{NEUROANATOMICAL ART}

The first true artistic illustrations of the brain, drawn on the basis of his own dissection, were made by Leonardo da Vinci [54]. The brain of an ox in his best drawing, made in 1508, was presented with the outlined cerebral hemispheres containing the ventricles. Leonardo obviously was influenced by the mentioned Herophilus' and Galen's vesicular doctrine about the brain ventricles as the seat of the human soul, i.e. the mentation process [15]. On the right part of the mentioned drawing there is a pale, hardly visible sketch of the human hemispheres in a superior view. Following enhancement of this part, a realistic presentation of the cerebral sulci and gyri can be noticed in the frontal, parietal and occipital regions.

The most famous anatomist of that time, André Vesalé alias Andreas Vesalius from Brusseles, made great progress in 1543 when he published at Padua University in Italy his book in Latin "De humani corporis fabrica" [68]. This masterpiece contained several dozens of plates in the woodcut technique, in which a precise delineation of the hemispheric convolutions is present, as well as outlines of the deep structures.

Somewhat later, in 1552, the Roman anatomist Bartolomeo Eustachio made fine copper engravings of the base of the brain, including the cerebellum

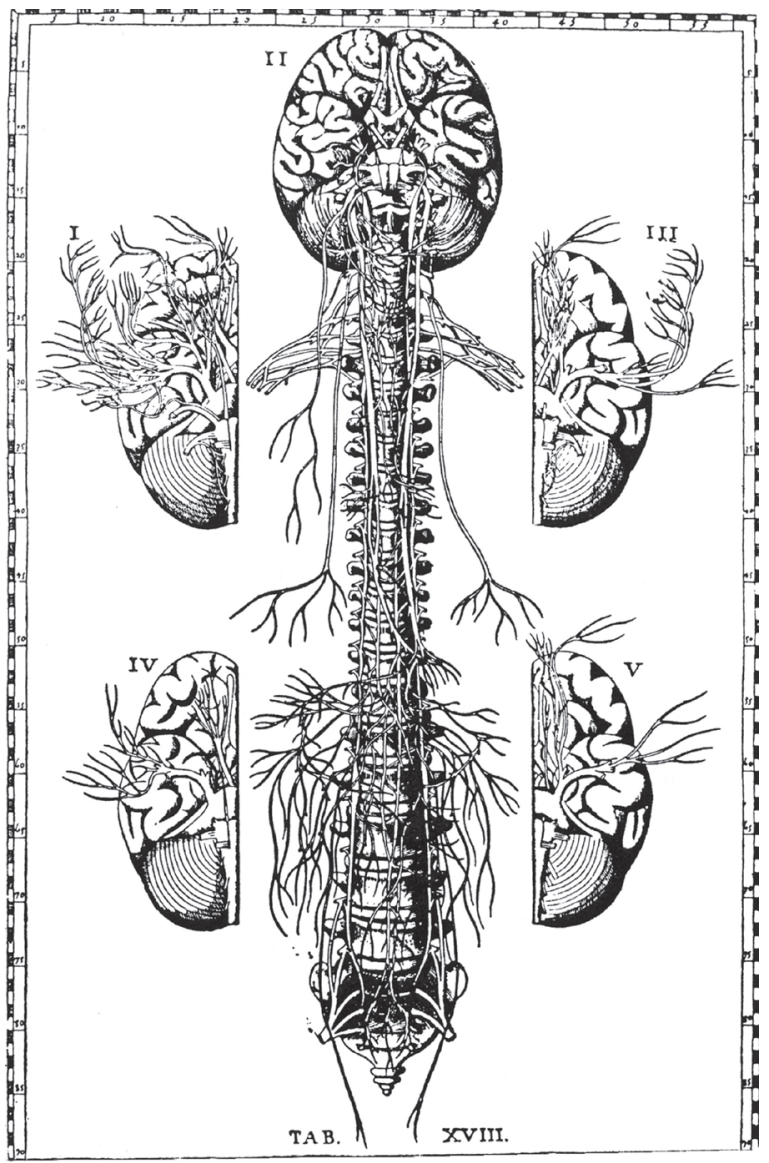

Figure 1. Plate with drawings by Bartolomeo Eustachio showing the cerebral convolutions at the base of the brain, the origin of the cranial nerves, and the sympathetic nervous system (Credit: Dover Publications, Inc., New York).

and certain nerves [71]. However, the cerebral convolutions were not presented very realistically, neither the orbital gyri of the frontal lobe nor convolutions of the temporal lobe (Fig. 1). On the other hand, the French physician Charles Estienne precisely depicted images of dissected brains in 8 out of the 62 woodcut plates in the 1545 book "De dissectione partium corporis humani".

The $17^{\text {th }}$-century French philosopher and mathematician René Descartes, known for his famous statement in Latin "Cogito, ergo sum" (I think, therefore I am), believed that the pineal gland, the only unpaired organ of the brain, was the seat of a rational soul or spirit that regulates the bodily functions [11]. Accordingly, he was the first to reject the medieval cellular theory of the mind. Thanks to an unknown artist, Descartes presented in his 1662 book "De homine" several drawings of the intact and dissected brains, respectively. In these illustrations, however, the cerebral convolutions were far from the reality. 


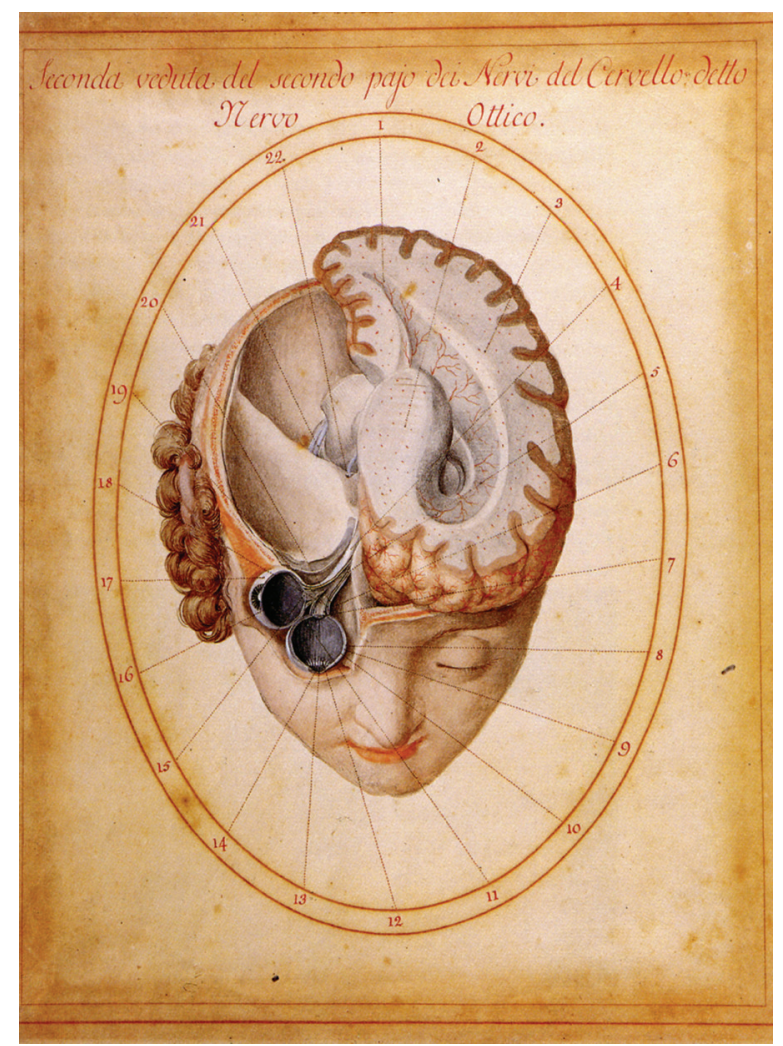

Figure 2. Illustration of the left hemisphere convolutions, and the right optic nerve. The $2^{\text {nd }}$ half of the $18^{\text {th }}$ century. Collection of "La Specola" Museum in Florence, Italy (Credit: Museo di Storia Naturale Università di Firenze, sez. Zoologica "La Specola" — Italia. Photo credit: Saulo Bambi — Museo di Storia Naturale/Firenze).

In 1664, Thomas Willis published in "De cerebri anatome" several drawings of the dissected brain, and also a well-known illustration of the base of the brain and the main cerebral vessels, whose anastomotic circle has been named after him [11]. Although Willis engaged the draftsman Cristopher Wren, who was famous for designing the St. Paul's Cathedral in London, the cerebral gyri were not presented very realistically. Among the Italian anatomists and artists in the same and the following century, who prepared specimens in wax, some of them created, prior to modeling, nice baroque drawings of the brain (Fig. 2) with idealised cerebral gyri.

Samuel Thomas Soemmering edited in 1799 "Über der Organ der Seele" (On the Organ of the Soul) with excellent drawings of the cerebral gyri [11]. Remarkable neuroanatomical illustrations in $18^{\text {th }}$-century England were produced by the surgeon Charles Bell in his book "The Anatomy of the Brain". Pierre Camper made a certain contribution to the French neuroanatomical literature. Parisian professor Jacques
Fabien Gautier D'Agoty published in the 1748 "Essai d'anatomie" several splendid colour pictures of the brain [48]. All of these authors presented precise images of the cerebral gyri in both the intact and sectioned brains.

A monumental "Atlas of Anatomy and Surgery" in several volumes was published in 1831 to 1854 in Paris by Jean Marc Bourgery [48]. The atlas, that was prepared in collaboration with the artist N.H. Jacob, contained 30 tables of the intact, dissected or sectioned brains. In all of them, the cerebral convolutions were drawn precisely, together with their pial arterial and venous network.

Among dozens of the atlases published in the $20^{\text {th }}$ century, the anatomically and artistically best images of the cerebral gyri, depicted by 3 painters, were edited by the Viennese professor Eduard Pernkopf [58], who was a brilliant anatomist but, unfortunately, also an active member of the Nazi Party [62]. Finally, high technology produced excellent computer images of the hemispheric convolutions, as well as fine holograms of the brain and head [46].

\section{ARTISTIC VIEW OF THE CONVOLUTIONS}

Among all the mentioned artists, Leonardo da Vinci was the first to depict the cerebral convolutions from both the artistic and scientific aspect [54]. Some scholars speculate that the famous fresco painting "Creation of Adam", by Leonardo's and Vesalius' contemporary Michelangelo Buonaroti, on the ceiling of Sistine Chapel in the Vatican resembles the brain in a sagittal section [27]. Andreas Vesalius also made a combination of the anatomy and fine art thanks to a collaboration with certain students of Tizian [68].

Nevertheless, the first painting of the brain and its gyri was made by Rembrandt Harmenszoon van Rijn in 1656 on the canvas "Anatomy Lesson of Doctor Joan Deijman" [5]. This brilliant artist naturalistically depicted the frontal cerebral convolutions with some leptomeningeal vessels during the autopsy of the executed thief Joris Fonteijn. As already mentioned, the first colour picture was made in the $18^{\text {th }}$ century as a preparation for a wax specimen modeling. In spite of an idealised presentation of the cerebral gyri, the drawing has certain aesthetic values due to the angle of view, composition and colouration (Fig. 2).

To our knowledge, the first artistic image of the brain from Leonardo and Rembrandt on was depicted by Victor Vasarely in 1930 on the canvas "Blue Study" (Fig. 3) [35]. This simplistical brain image shows only 


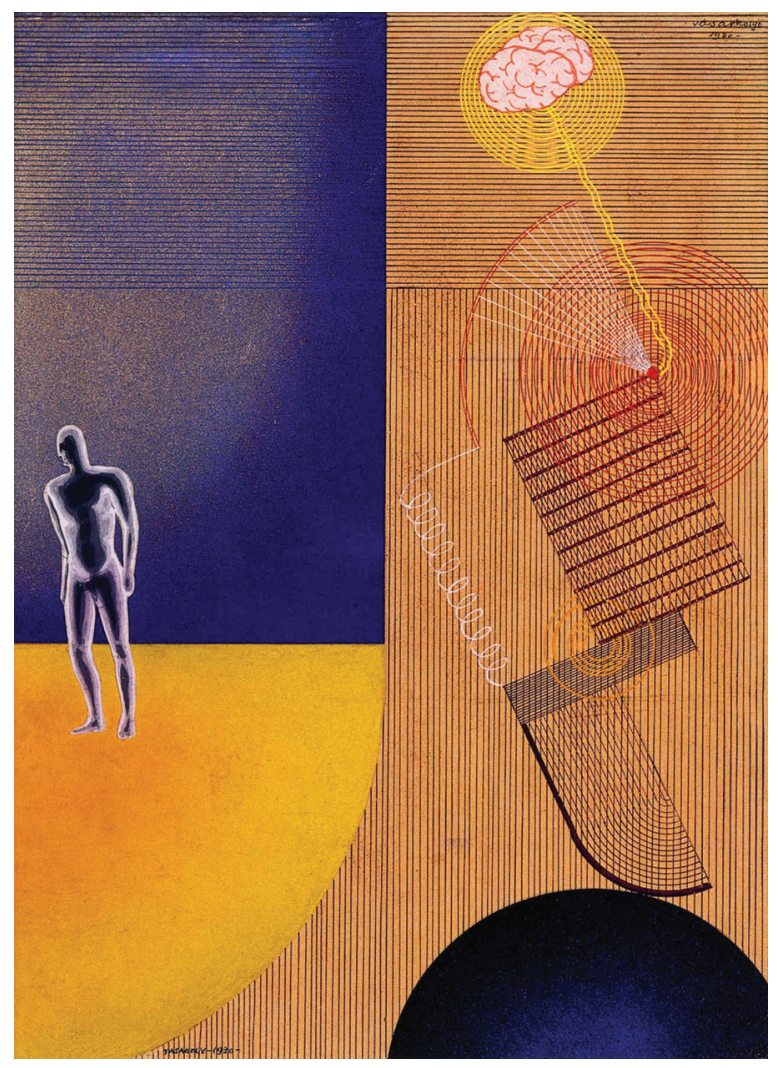

Figure 3. Victor Vasarely: "Blue Study", 1930. The brain image is seen in the upper right corner of the painting (Credit: ${ }^{\odot}$ ADAGP, Paris 2011).

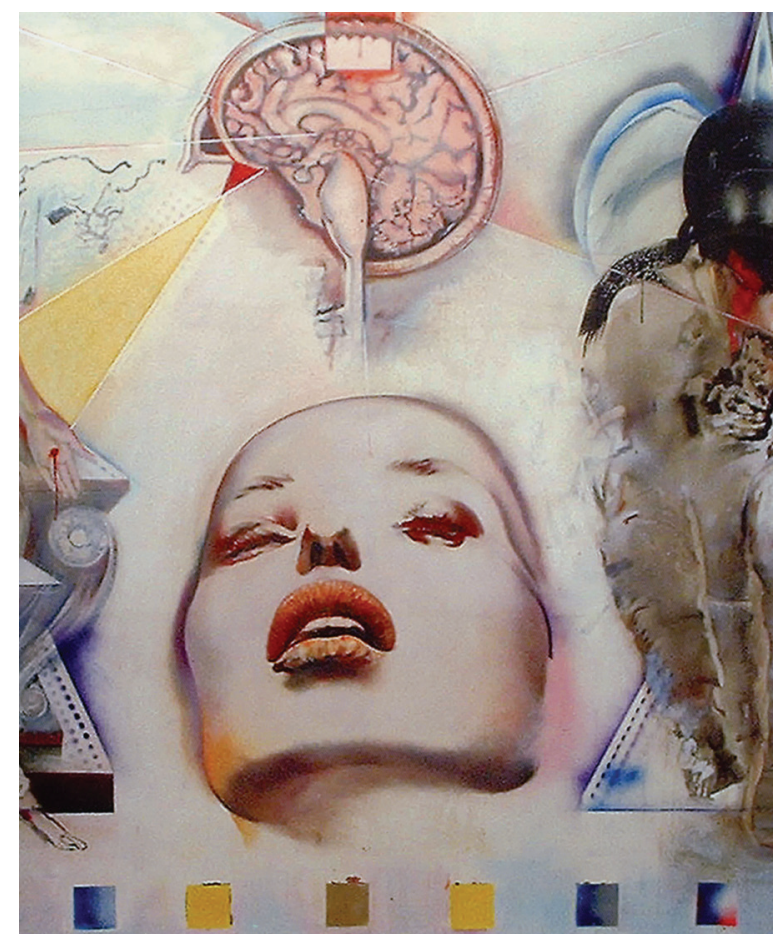

Figure 4. Medial surface of the right hemisphere in situ on the canvas "Brain Storm", painted by Olja Ivanjicki. Detail (Credit: Novosti Company; Olga Olja Ivanjicki: Eternal Conditions, Beograd, 2008). a few schematic, unrealistic cerebral convolutions. A few decades before him, a futurist author Umberto Boccioni created a metaphorical series "States of Mind". Some 30 years after Vasarely, an artistic drawing of the left hemisphere was made, and published later in H.R. Giger's book, with relatively precisely outlined gyri of the superolateral hemispheric surface [30].

Modern artists, however, show more interest in presenting the brain and cerebral convolutions. Thus, Olja Ivanjicki painted the medial hemispheric gyri on the canvases "The Brain Storm" (Fig. 4) and "Agony and Ecstasy of Dr. Wilmut", respectively [37]. The famous surrealist Salvador Dalí made a simple drawing of the hemisphere, like an island in the sea, entitled "Memory" [16]. The British artist Helen Chadwick presented the cerebral convolutions from the superior view in several modified photographs of the hemispheres, for example, in "Self-Portrait and Eroticism". Constance Jacobson painted the convolutions in the composition "Leakage", as well as in the "Gyri" series. The latter author modified the brain images to present various mood states.

Anselm Kiefer depicted a gradually decomposing brain in his artistic cycle "The German Spirit" [47]. Luigi Di Castro created the images "Brain and Mind", respectively, Istvan Orosz produced "Brain Maze", and Claire Davies "Butterfly Brain". The American artist Alex Grey presented dozens of brain images in his series "Sacred Mirrors" and in many individual works. Most of the mentioned artists, who applied oil or acrylic painting, photographs modification, or digital technique, presented the cerebral gyri in a metaphorical or conceptual manner.

Modern technology, science fiction and new ideas influenced brain art like all other fields of creativity $[13,33,34,36]$. Thus, the digital artist Frederic Durville made the cerebral gyri which do not create the brain but another convoluted structure. Dylan Delosangeles depicted the cerebral sulci and gyri like an electronic integral circuit. Some creative groups produced colourised photoshopped or 3-dimension images of the convolutions (Fig. 5). Bill Scott has developed a method to visualise electroecephalographic brain activity and thus to get pleasing artful images. Christian Yoder created the digital artwork "The Phantom Planet" with the brain shape, colour and gyri patterns of an imaginative extraterrestrial creature [33].

The first models of the cerebral convolutions in history were created in wax by Italian artists and anatomists. Modern author Jan Fabre made several 


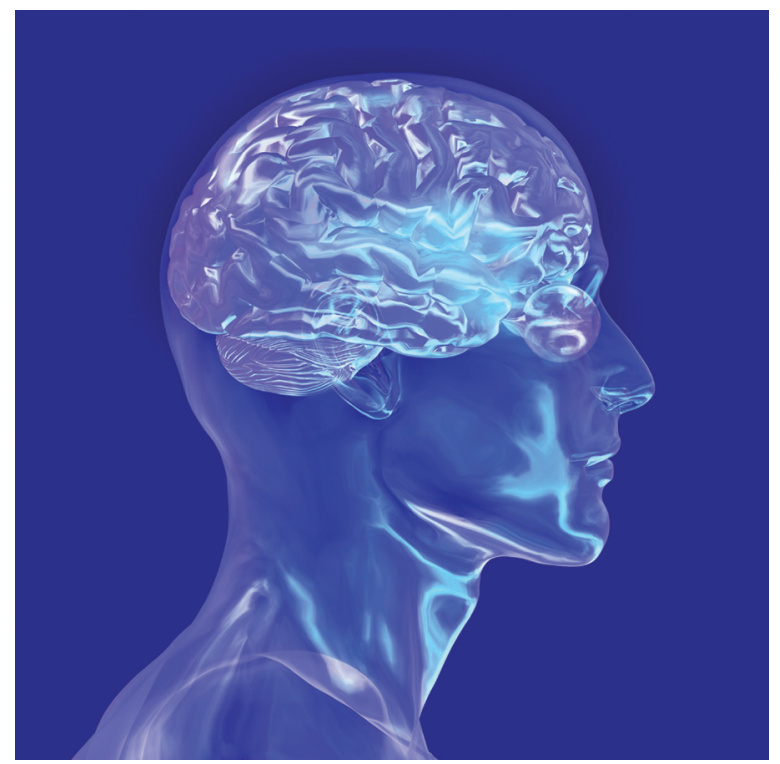

Figure 5. Digital image of the cerebral convolutions entitled "Glass Head with Brain" (Credit: Fotosearch, 2011).

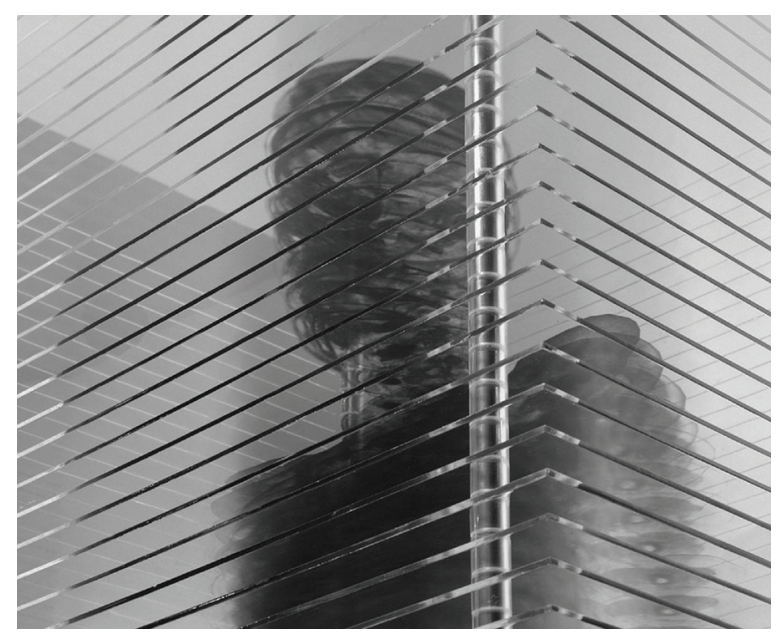

Figure 6. Sculpture "Sophie" (detail) created of the serial computed tomography images by Mariléne Oliver (Courtesy of Mariléne Oliver and Beaux Arts).

almost anatomical models of the brain with the recognizable main cerebral gyri in his series "From the Feet to the Brain". Paul Richardson produced a huge brain model for Gainsborough Library, whereas Anne and Patrick Poirier made a similar brain sculpture in marble with all the gyri of the superolateral surface. Brian Christensen created brass convolutions on the top of a trombone sculpture entitled "One Man Band". Metal brain sculptures were also produced by Annie Cattrell [44]. Loris Marazzi made a wooden model of the brain in two hands entitled "My Mind, my Force". Merijn Bolink had a different idea when creating a brain sculpture whose convolutions were modeled like certain animals [47].

Fiona Hall and Jessica Lloyd-Jones made the glass convolutions, while Katharine Dawson created a glass model based on the magnetic resonance imaging (MRI) scans of her own brain. Theo van der Hoeven modeled only cerebral sulci using steel wires. Dustin Yellin made "The Invisible Man", i.e. a transparent figure with the brain visible inside the head. Mariléne Oliver created original sculptures assembled of the serial MRI or computer tomography scans printed on acrylic sheets (Fig. 6).

Obviously, the brain and mind were the subject of many scientists and philosophers but, until the $20^{\text {th }}$ century, only of a minority of artists. According to our examination, out of the 27,614 artworks only $234(0.85 \%)$ contained an image or a model of the brain, which were created by 67 out of 2,856 (2.35\%) professional artists, medical experts, photographers, digital artists or designers [51]. They performed drawings, woodcut, copper engravings, etchings, paintings, photographs, radiological images, digital works or brain sculptures.

From Leonardo in 1508 to Vasarely in 1930, we found out only 2 artistic images of the brain, i.e. the mentioned Italian colour picture and Rembrandt's painting, as well as a few wax models. Artists in the past centuries failed to depict the brain for at least 2 reasons. Firstly, from the renaissance on they were much more interested in the external beauty of the human body than in the aesthetics of the internal organs $[13,74]$. Secondly, in spite of great progress in the neuroanatomy [11], many of the artists had inadequate knowledge of neuroscience. Those who did have it, helped the neuroanatomist to create the artistic illustrations for their professional books $[32,68]$.

However, the artists of the first half of the $20^{\text {th }}$ century, especially the dadaists and surrealists [13, $16,22]$, had sufficient knowledge of neuroscience but seemed to lack of courage to paint the brain, such a mighty and still a mysterious organ. This is, perhaps, why an artist like Salvador Dalí, who depicted all the possible objects and scenes based on the Freudian theory about dream contents and the unconscious mind, virtually failed to depict the brain, except in the mentioned drawing "Memory". Instead, he put into the empty heads of his painted figures the images of flowers, sea shells, and even the lit candles. Similarly, 
the dadaist Marcel Duchamp, who probably had the greatest freedom in creativity of all the artists, also failed to present the brain [22]. We think that only psychoanalysis can give a definite explanation of this phenomenon.

Some contemporary authors, on the other hand, relatively often paint and model the cerebral gyri or modify the brain photographs or neuroradiological images [37, 47, 50, 51, 73]. Some of them presented precisely the brain convolutions, but many others in a less realistic manner. Nevertheless, the artists are not expected to present reality and scientific facts, including the anatomical images of the cerebral gyri $[13,75]$. They are, rather, supposed to show the brain in a symbolic, metaphorical or allegorical manner, in any case with certain conceptual background. The artistic view was elegantly explained by painter Paul Klee: "Not to reproduce what we can already see, but to make visible what we cannot" [57].

\section{ARTISTIC AND EVOLUTIONARY SIMILARITIES}

The cerebral convolutions have various appearances and patterns in different regions of the human brain, as well as in the cerebrum of different mammals $[19,55]$. Their general shape and arrangement resemble, in some way, the drawing "Hair" by Henri Matisse, "The Amselfluh" painted by Ernst Ludwig Kirchner, "Ciurana, the Path" depicted by Joan Miró, and "Dune Landscape" by Piet Mondrian [8, 13, 65, 76].

Nature created brain convolutions in order to make possible a relatively fast evolutionary development of the cerebral cortex without a marked increase in the brain volume [6,9]. Thanks to this, the hemispheric convolutions, with a mean cortical thickness of about $3.5 \mathrm{~mm}$ and with total surface area of approximately $1,600 \mathrm{~cm}^{2}$, enabled the human brain to be comfortably positioned in a relatively small intracranial cavity $[3,63]$.

Some artists were inspired by the similarity of the cerebral gyri to other types of convolutions in the living world [9]. For example, of the walnut core, then Mexican type of cacti with a gyri-like surface (Fig. 7), and of a sort of the sea coral with similar appearance (Fig. 8). Stimulated by these analogies, Marija Karanfilović depicted the brain convolutions in a walnut shell (personal communication, 2012), while Jake Richter digitally painted the "Brain Coral".

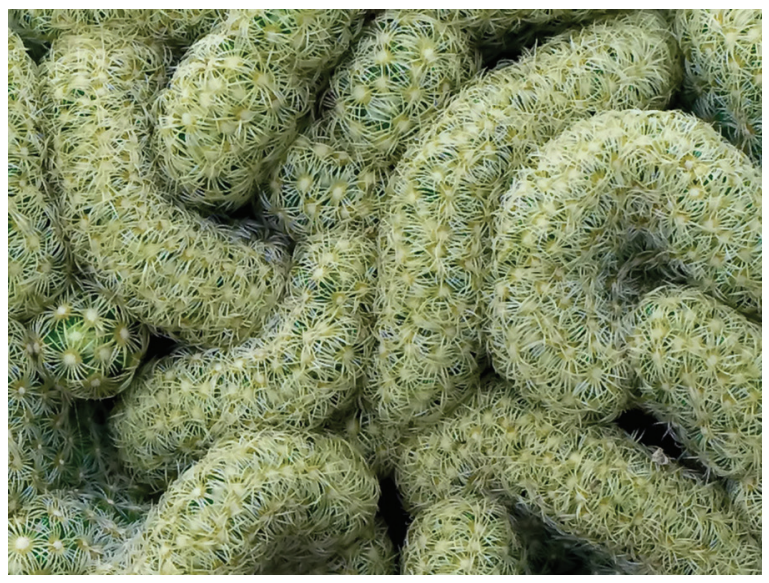

Figure 7. Brain cactus (Courtesy of Daniel Mosquin: daniel.mosquin @ubc.ca).

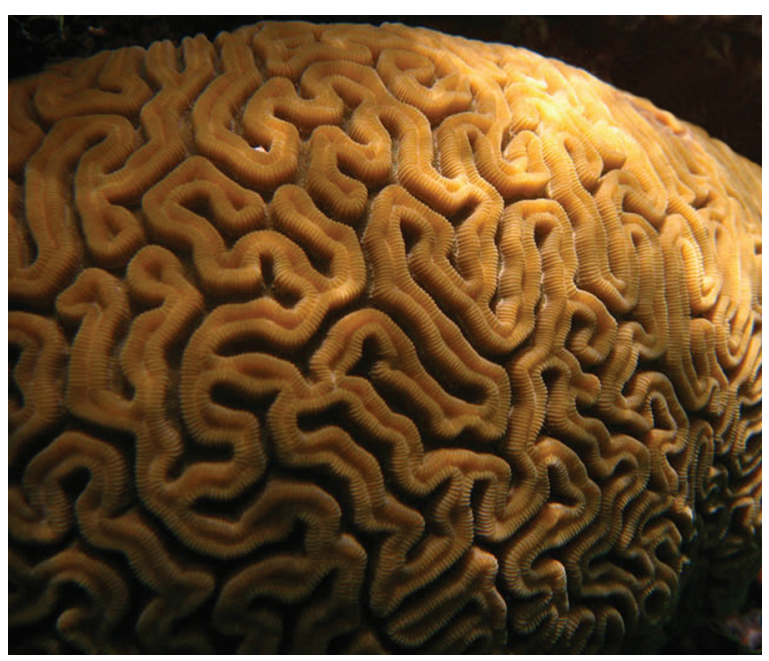

Figure 8. Brain coral, photographed by Jaro Nemcok (Courtesy of Jaro Nemcok, http://nemcok.sk/).

\section{NEUROSCIENCE AND PATHOPHYSIOLOGY}

Some diseases or disorders affecting the cerebral convolutions have found their place in art. For example, epilepsy, which has been still described in the treatise "On the Sacred Disease" from the "Hippocrates Corpus," was later on depicted in Fra Fillipo Lippi's painting "St. Zeno exorcising the Daughter of Emperor Gallienus", and on Raphael's canvas "The Transfiguration" [7, 27, 71]. The gifted French physician Paul Richer of the $20^{\text {th }}$ century modeled a statuette of a patient with "Parkinson's disease" [43].

Billions of the interconnected neurons form the cortical layers of the cerebral convolutions $[1,10]$. The 


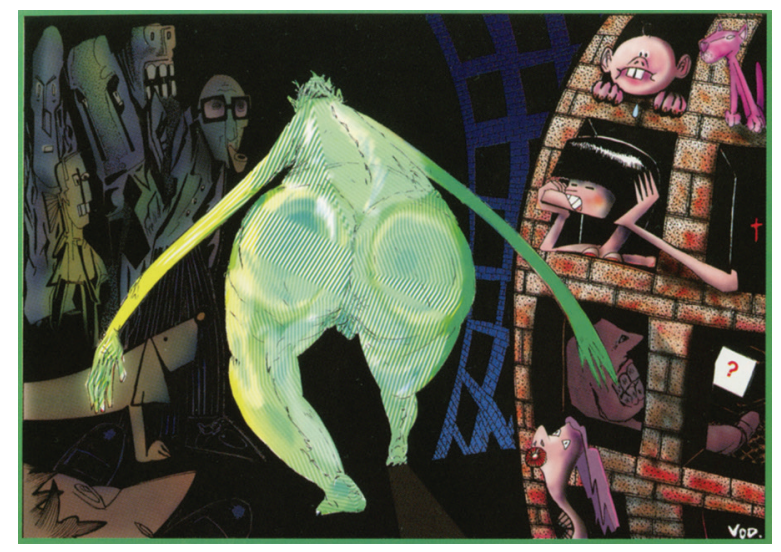

Figure 9. Digital image "Alzheimer" created by Vod Land (Credit: Grant $\mathrm{J}$, Vysniauskas A. Digital art of the $20^{\text {th }}$ century. Renderosity, AAPPL, London, 2003, c/o info@aappl.com).

neurons are generated in the ventricular zone of the embryonic brain, from where they migrate superficially to form the cerebral cortex [38]. Any disturbance in the migration process leads to a disorder in the organisation and function of the cortex, what is often manifested postnatally as the epilepsy or mental retardation [25]. Some of these disorders are expressed morphologically as the absence of the cerebral convolutions (lissencephaly or agyria). The opposite event is also possible, that is, a larger number of the small convolutions (polymicrogyria) associated with mental disorders [26].

None of artists and neuroscientists were affected by these congenital or genetic disorders, but certain of them suffered from some of the neurological and related diseases which mainly affected the cerebral gyri [43]. For example, the painter Vincent van Gogh and the writer Dostoevsky had troubles with epilepsy and depression $[21,66]$. The ingenious artist and scientist Leonardo da Vinci and the distinguished modern neuroanatomist $A$. Brodal experienced a stroke with hemiparesis, and the composer Maurice Ravel with hemiplegia and aphasia. The German painter Räderscheidt and the famous Italian film director Fellini manifested a neglect syndrome. Peter Medawar, who won the 1960 Nobel Prize for medicine, as well as Russian composer Prokofiev and Norwegian writer Ibsen, experienced an intracerebral haemorrhage. The French film director Truffeaut and the American conductor Bernstein had brain tumors. The neoplasms inspired the modern artist Rosemary Covey to create the "Brain Tumour" series.

Not only the neurological but also the psychiatric diseases, that are based on certain neurotransmitters' disturbances with a consecutive cortical dysfunction [41, 42], have been presented by some artists. Thus, Pieter Bruegel depicted, most likely, a schizophrenic patient on the canvas "Dulle Griet", Francisco de Goya painted a few scenes from a mental hospital, while Théodore Gericault depicted portraits of several patients with paranoid psychosis, i.e. delusional disorder $[13,77]$. Albrecht Dürer, Edvard Munch and Salvador Dalí presented depression on the canvases "Melancholy and Melancholia atomica", respectively $[13,16]$. Richard Tuschman made a collage-like composition "Aging and the Brain", while Vod Land created a digital artwork entitled "Alzheimer" (Fig. 9) [33].

Many artists, scientists and thinkers displayed some unusual behaviour or certain psychiatric disorders $[2,16,28,42,45,67]$. Albert Einstein, for instance, was known for his awkward and informal behaviour. On the other hand, the poets Byron and Rimbaud, as well as artists Caravaggio and Cellini, expressed temper, and adventurous and unrestrained behaviour. The latter two have even been accused of committing murder. Salvador Dalí exhibited an extravert and eccentric personality, which also included certain anxiety disorders. The famous philosopher Friedrich Nietzsche had mental disturbances due to neurosyphilis.

Some of painters and sculptors suffered from schizophrenia, for example, William Blake, Franz Messerschmidt, Alfred Kubin and Bryan Charnley, some others probably from hypomania or bipolar disorder, like Rembrandt van Rijn and Pablo Picasso [52]. The majority of them, however, manifested a depressive disorder or major depression: Francisco Goya, Théodore Gèricault, Paul Cézanne, Paul Gauguin, Vincent van Gogh, Edvard Munch, Joan Miró, Jackson Pollock, Marc Rothko and Bernard Buffet, some of whom committed suicide $[2,60]$. It is almost as if their illness was a prerequisite or an inciter of their creativity, as well as the price they had to pay for their ingenious minds.

\section{ART AND SCIENCE OVERLAPPING}

Tight interconnections exist between art and science, which can be considered from several aspects. Firstly, there is an influence of the art on science. Some anatomists and surgeons in the past centuries were good artists as well, such as Andreas Vesalius, Leonardo da Vinci, Charles Bell and Pierre Camper $[11,68]$. Similarly, the famous $20^{\text {th }}$-century neurosurgeon Harvey Cushing used to document his own studies through excellent drawings of the head and 
brain [27]. Several modern neuroscientists, who are art lovers, have tried to examine the cognitive basis for artistic creativity, thus founding neuroaesthetic science [4, 24, 49, 77, 78].

The renaissance age was characterised by a "marriage of art and anatomy" [32]. A lot of anatomists and neuroanatomists engaged professional artists in preparing brilliant illustrations of the brain in their books [11, 15, 48, 68]. Andreas Vesalius collaborated with students of Tizian, especially with Jan Stefan van Calcar, some other anatomists engaged Antonio Pollaiuolo, Andrea Mantegna, Gentile Bellini and Albrecht Dürer. Some painters had a collaboration with certain anatomists: Michelangelo worked with Realdo Colombo, and Leonardo started collaboration with Marcantonio della Torre after conducting his own dissections. All the mentioned painters, along with Verocchio, Signorelli, Raphael (Raffaello) and Tizian (Tiziano), were also practicing dissections. They not only improved art, but also the anatomy and neuroscience.

The linear perspective, whose neuroanatomical basis are the occipital and parietal visual areas, was discovered and elaborated in the $15^{\text {th }}$ century, yet not by mathematicians but by architects, sculptors and painters such as Bruneleschi, Masaccio, Donatello, Ghiberti, and Uccello [11, 27, 32]. The linear perspective was then codified by the architect Battista Alberti and described by the painter Piero della Francesca in "De perspectiva pingendi" ("On the Perspective in Painting"). This achievement greatly improved art, including brain presentation in the anatomical publications, but also mathematics, geometry, engineering and architecture.

There are also certain examples of the influence of science on art. The brilliant renaissance painter Raphael, inspired by ancient Greek scientists and philosophers, depicted the well-known mural "The School of Athens" with portraits of Plato, Aristotle, Diogenes, Euclid, Averroës, Pythagoras and Ptolemy [7]. Later on, in the $18^{\text {th }}$ century, Joseph Wright painted a scene entitled "An Experiment on a Bird in the Air-Pump" [77]. Ford Madox Brown, inspired by John Dalton's discovery of methane, painted in 1880 a mural entitled "Dalton Collecting Marsh-Gas Fire". In the same century, the French painters Georges Seurat and Paul Signac, following the rules of the new colour theories, divided the monochromatic colours (hence the name "divisionism"), that is, they presented them as the separated dots side by side (hence the name "pointillism"), and thus created the optically original paintings $[65,74]$.

In the $20^{\text {th }}$ century, the Mexican painter Diego Rivera depicted the huge mural "History of Medicine", which was completely inspired by the biological and medical sciences [13]. The surrealist Salvador Dalí, influenced by great progress in quantum physics, astronomy and genetics depicted or modeled "The Spectral Cow, Intra-Atomic Equilibrium of a Swan's Feather", "Nuclear Cross, Searching for the Fourth Dimension, Cybernetic Odalisque", and even a metaphorical DNA of his wife Gala entitled "Galacidalacidesoxyribonucleidacid" [16].

Some modern artists are inspired by tremendous progress in neuroscience, especially in neural connectivity. Thus, Constance Jacobson, Geoffrey Koetsch and Andrew Carnie created works of art that resemble the cortical neural networks [44]. The artists Audrey Goldstein, Mary Kaye and Karl Nussbaum were trying to present certain mental processes in their paintings, installations, sculptures and movies. Some others, such as Alex and Allyson Grey, were focused in their art on visions and mystical experiences triggered by psychedelic drags.

Finally, many of the mentioned artists made attempts to elaborate certain unresolved problems in modern neuroscience. This is especially true for the mystery of how our neural matter within the cerebral gyri produces consciousness, self-consciousness, thoughts, emotions and other highly abstract cognitive phenomena [44]. Probably, artistic intuition, $\mathrm{Hi}$-Tech neuroscientific work and the reasoning of philosophers could be a starting point for the discovery of the essence of such a "cosmic" problem. Yet, a crucial question remains unanswered by both artists and scientists: is our mind capable at all to reveal its own essence [29]?

\section{CONCLUSIONS}

The hemispheric convolutions, which are the seat of the human spirit, i.e. man's personality and cognitive functions, were often presented in anatomical literature by engaging certain draftsmen and painters. Professional artists themselves less frequently depicted the cerebral gyri for their own sake until the $20^{\text {th }}$ century. In modern times, however, somewhat larger number of painters, sculptors, photographers, radiologists and digital artists devoted their creativity to brain and gyri artworks. They were inspired by the aesthetics of cerebral convolutions, progress in neu- 
roscience, cerebral pathology and especially by the brain as the seat of the mind. Art and neuroscience are obviously interrelated and overlapping domains of the same mental processes. Both types of creativities represent a fascinating product of billions of the interconnected cortical neurons housed in the cerebral convolutions.

\section{ACKNOWLEDGEMENTS}

This work was supported by grant no. 175061 from the Ministry of Science, Serbia.

We are very grateful to Mrs. Elza Holt for reviewing the English text of our manuscript.

\section{REFERENCES}

1. Amaral DG (2000) The anatomical organization of the central nervous system. In: Principles of neural science. McGraw-Hill, Health Professions Division, New York, pp. 317-348.

2. Barger $P$ (1998) Creativity and psychic distress in artists, writers and scientists: implications for emergent models of psychiatric nursing practice. J Psychiatr Ment Health Nurs, 5: 109-117.

3. Barta P, Dazzan P (2003) Hemispheric surface area: sex, laterality and age effects. Cereb Cortex, 13: 364-370.

4. Bhattacharya J, Petsche H (2002) Shadows of artistry: cortical synchrony during perception and imagery of visual art. Cogn Brain Res, 13: 179-186.

5. Bolten J Bolten-Rempt H (1976) Rembrandt, Arnoldo Mondadori Editore S.p.A., Milano (Italian).

6. Brodmann K (1909) Vergleichende Lokalisationlehre der Grosshirnrinde in ihren Prinzipien dargestellt auf Grund des Zellbaues, JA Barth, Leipzig [In German].

7. Buck S, Hohenstatt P (2007) Masters of Italian art. Raffaello Santi, known as Raphael, h.f. Ullmann, Königswinter.

8. Butler S (1995) Miró, Studio Editions, London.

9. Campbell NA, Reece JB, Mitchell LG, Taylor MR (2003) Biology. Concepts and connections, Benjamin Cummings, San Francisco.

10. Carpenter MB (1991) Core text of neuroanatomy. Williams and Wilkins, Baltimore.

11. Cavalcanti DD, Feindel W, Goodrich JT, Dagi FT, Prestigiacomo CJ, Preul MC (2009) Anatomy, technology, art, and culture: toward a realistic perspective of the brain. Neurosurg Focus, 27: 1-22.

12. Cormack R (2000) Byzantine art. Oxford University Press, New York.

13. Davies PJE, Denny WB, Hofrichter FF, Jacobs J, Roberts AM, Simon DL (2007) Janson's history of art. The Western tradition, Pearson Prentice Hall, Upper Saddle River.

14. Debernardi A, Sala E, D'Alberti G, Talamonti G, Franchini AF, Collice M (2010) Alcmaeon of croton. Neurosurgery, 66: 247-252

15. Del Maestro RF (1998) Historical vignette. Leonardo da Vinci: the search for the soul. J Neurosurg, 89: 874-887.

16. Descharnes R, Néret G (2006) Salvador Dalí, Taschen, Köln.
17. Dornald I, Newman WA (2003) Dorland's illustrated medical dictionary, Saunders, Elsevier, Philadelphia.

18. Duby G, Daval JL (2006) Sculpture. From antiquity to the middle ages, and from the renaissance to the present day. Vol. 1, 2. Taschen, Köln.

19. Duvernoy HM (1999) The human brain. Surface, three-dimensional sectional anatomy with MRI, and blood supply, Springer, New York.

20. Eickhoff SB, Rottschy C, Kujovic M, Palomero-Gallagher N, Zilles K (2008) Organizational principles of human visual cortex revealed by receptor mapping. Cereb Cortex, 18: 2637-2645.

21. Elger D (2007) Expressionism, Taschen, Köln.

22. Elger D (2006) Dadaism, Taschen, Köln.

23. Fahr-Becker G (2006) The art of East Asia. Könemann, Köningswinter.

24. Fairhall SL, Ishai A (2008) Neural correlates of object indeterminacy in art compositions. Conscious Cogn, 17: 923-932.

25. Foldvary-Schaefer N, Bautista J, Andermann F, Cascino G, Spencer S (2004) Focal malformations of cortical development. Neurology, 62: (suppl. 3): S14-S19.

26. Frosch MP, Anthony DC, De Girolami, U (2005) The central nervous system. In: Robbins and Cotran pathologic basis of disease. Elsevier Saunders, Philadelphia, pp. 1347-1419.

27. Geranmayeh F, Aschkan K (2008) Mind on canvas: anatomy, signs and neurosurgery in art. Br J Neurosurg, 22: 563-574.

28. Gibson M (2006) Symbolism, Taschen, Köln.

29. Gierer A (2008) Brain, mind and limitations of a scientific theory of human consciousness. Bioessays, 30: 499-505.

30. Giger HR (2007) HR Giger Arh+, Taschen, Köln.

31. Giles B (2002) The human computer. In: Thinking and knowing, Grange Books, Hoo, pp. 6-23.

32. Ginn SR, Lorusso L (2008) Brain, mind, and body: interactions with art in renaissance Italy. J Hist Neurosci, 17: 295-313.

33. Grant J, Vysniauskas A (2004) Digital art for the $21^{\text {th }}$ century. Renderosity. Artists' and Photographers' Press Ltd., London.

34. Heller S, Ilić M (2007) The anatomy of design. Rockport Publishers, Inc. Gloucester.

35. Holzhey M (2005) Victor Vasarely, Taschen, Köln.

36. Holzwart HW (2009) 100 contemporary artists. Vol. 1, 2, Taschen, Köln.

37. Hubbard S (2009) Olja Ivanjicki. Painting the future. Philip Wilson Publishers Ltd., London.

38. Jessell TM, Sanes JR (2000) The generation and survival of nerve cells. In: Principles of neural science. McGraw-Hill, Health Professions Division, New York, pp. 1041-1062.

39. Kahle W (1969) Die Entwicklung der menschlichen Grosshirnhemisphäre. Springer-Verlag, Berlin [In German].

40. Kandel ER (2000a) The neurobiology of behavior. In: Principles of neural science. McGraw-Hill, Health Professions Division, New York, pp. 5-18.

41. Kandel ER (2000b) Disorders of mood: depression, mania, and anxiety disorders. In: Principles of neural science. McGraw-Hill, Health Professions Division, New York, pp. 1209-1226.

42. Kaplan HJ, Sadock BJ (2003) The brain and behavior. In: Kaplan Sadock's synopsis of psychiatry, behavioral sciences/ clinical psychiatry. Lippincott Williams \& Wilkins, a Walters Kluwer Company, Philadelphia, pp. 66-135. 
43. Kapur N (1997) Injured brains of medical minds. Views from within, Oxford University Press, Oxford.

44. Koetsch G (2011) Artists and the mind in the $21^{\text {st }}$ century. Front Hum Neurosci, 5: 1-8.

45. Kosslyn SM, Rosenberg RS (2004) Language and thinking. In: Psychology. The brain, the person, the world. Pearson Education, Inc., Boston, pp. 298-345.

46. Kretschmann HJ, Weinrich W (2004) Topography of the neurocranium and its intracranial spaces and structures in multiplanar parallel slices. In: Cranial neuroimaging and clinical neuroanatomy. Atlas of MR imaging and computed tomography. Thieme, Stuttgart, pp. 236-324.

47. Lakke JPWF (1999) Artful imaging of the brain. From logo to metaphor, about Michelangelo and Kiefer. Arch Physiol and Biochem, 107: 1-14.

48. le Minor JM, Sick H (2005) The atlas of anatomy and surgery by JM. Bourgery and N.H. Jacob - a monumental work of the $19^{\text {th }}$ century, Taschen, Köln.

49. Lengger PG, Fischmeister FPS, Leder H, Bauer H (2007) Functional neuroanatomy of the perception of modern art: A DC-EEG study on the influence of stylistic information on aesthetic experience. Brain Res, 1158: 93-102.

50. Lucie-Smith E (1977) Art today. From abstract expressionism to superrealism. William Morrow, New York.

51. Marinković S, Stošić-Opinćal T, Štrbac M, Tomić I, Tomić O, Djordjević D (2010) Neuroradiology and art: a review and personal contribution. Tohoku J Exp Med, 222: 297-302.

52. Mathey $F$ (1976) Il cubismo. La ricerca della struttura delle cose, Fratelli Fabbri Editori, Milano [In Italian].

53. Momjian S, Seghier M, Seeck M, Michel CM (2003) Mapping of the neuronal networks of human cortical brain functions. Adv Tech Stand Neurosurg, 28: 91-142.

54. Nathan J (2007) Anatomical drawings. In: Leonardo da Vinci. The complete paintings and drawings. Taschen, Köln, pp. 400-479.

55. Ono M, Kubik S, Abernathey CD (1990) Atlas of the cerebral sulci. Georg Thieme Verlag, Stuttgart.

56. O'Rahilly R, Müller F (2001) Human embryology and teratology. Wiley-Liss, A John Wiley and Sons, Inc., Publications, New York.

57. Partsch S (2006) Paul Klee, Taschen, Köln.

58. Pernkopf E (1963) Atlas of topographical and applied human anatomy. Head and neck. Vol. 1. W. B. Saunders Company, Philadelphia.
59. Persaud TVN (1984) Early history of human anatomy. From antiquity to the beginning of the modern era. Charles $C$ Thomas Publishers, Springfield.

60. Preti A, Miotto $P$ (1999), Suicide among eminent artists. Psychol Rep, 84: 291-301.

61. Rhoton AL (2002) The supratentorial cranial space: Microsurgical anatomy and surgical approaches. Neurosurgery, 51: (suppl.): S1-S410.

62. Riggs G (1998) What should we do about Eduard Pernkopf's atlas? Acad Med, 73: 380-386.

63. Roberts N, Puddephat MJ, McNulty V (2000) The benefit of stereology for quantitative radiology. Review article. $\mathrm{Br}$ J Radiol, 73: 679-697.

64. Rose-Marie, Hagen R (2005) Egypt. People-gods-pharaohs, Taschen, Köln.

65. Ruhrberg K, Schneckenburger S, Fricke M, Honnef K (2005) Art of 20th century. Painting, sculpture, new media, photography. Vol. 1, 2. Taschen, Köln.

66. Russoli F (1967) Il postimpressionismo. Le origini del' arte moderna. Fratelli Fabbri Editori, Milano [In Italian].

67. Rustin TA (2008) Using artwork to understand the experience of mental illness: mainstream artists and outsider artists. Psychosoc Med, 5: 1-22.

68. Saunders JB deCM, O'Malley CD (1973) The illustrations from the works of Andreas Vesalius of Brussels. Dover Publications Inc., New York.

69. Siebler M (2007a) Greek art. Taschen, Köln.

70. Siebler M (2007b) Roman art. Taschen, Köln.

71. Singer C (1957) A short history of anatomy from the Greeks to Harvey. Dover Publications, Inc., New York.

72. Skinner HA (1970) The origin of medical terms. Hafner Publishing Company, New York.

73. Stangos N (2006) Concepts of modern art. From fauvism to postmodernism. Thames and Hudson World of Art, London.

74. Walther IF (2005) Impressionism. Taschen, Köln.

75. Wijdicks EFM, Wijdicks CA (2006) The portrayal of coma in contemporary motion pictures. Neurology, 66: 1300-1303.

76. Wolf N (2003) Ernst Ludwig Kirchner. Taschen, Köln.

77. Zeki S (2001) Artistic creativity and the brain. Science, 293: $51-52$

78. Zeki S, Lamb M (1994) The neurology of kinetic art. Review article. Brain, 117: 607-636. 